(the United Steel Companies, Ltd., Research and Development Department) for his paper "Continuous Rod and Bar Mills" (presented at Engineers Group meeting, November 29, 1962, to be published in the April issue of the Institute's Journal).

\section{The Comparative Administration Trust}

THE Comparative Administration Trust is organizing a course in collaboration with the London County Couneil Education Department on "The Use of Case Studies in the Teaching of Administration and the Commercial and Industrial Subjects" at Kingsgate College, Broadstairs, Kent, during June 3-6. The Trust is also organizing courses on "Administration and Management of Research and Development" to be held at Gonville and Caius College, Cambridge (July 14-August 9), Queen's College, Oxford (September 1-28), and Sundridge Park Management Centre, Bromley, Kent (November 10-December 7). Application forms and further information can be obtained from the Comparative Administration Trust, $30 \mathrm{St}$. George Street, Hanover Square, London, W.1.

Training Programme in the Physiology of Reproduction

THE Worcester Foundation for Experimental Biology, Shrewsbury, Massachusetts, has announced a postdoctoral training programme in the physiology of reproduction under a grant from the Population Council, Inc. The programme will start on July 1, 1964. Fellowships for the programme are to be awarded to candidates possessing a Ph.D. or M.D. degree, or their equivalents. These fellowships will carry a stipend of 5,500 dollars per annum and will be for a twelve-month period. An allotment will also be made for round-trip travel to Shrewsbury, Massachusetts. Application forms may be obtained from the Program Director and should be returned not later than September 1, 1963. They will be processed by an Advisory and Selection Committee of experts, and the fellowship awards will be announced by December 1 .

The programme will consist of a course of lectures and laboratory work. During the latter part of the year, each Fellow will have the opportunity of participating in a research project pertinent to his interests and within the capacity of the programme.

\section{Training Course in Polarography}

THE Department of Physical Chemistry, Charles University, and the Polarographic Institute of the Czochoslovak Academy of Sciences are organizing a training course in "Polarography" during July 15-27. The course, which will consist of lectures explaining the principles of the method given in English, German and Russian, and practical training, is essentially intended for graduates, but no preliminary knowledge of polarography is required. The number of participants is limited to twenty persons. The course will be prepared under the supervision of Prof. J. Heyrovsky, and the lectures and practical training will be given by members of Charles University and the Polarographic Institute. The fee is $K \check{c} s$ 300-which includes practical training expenses, a sight-seeing journey and a dinner, but does not include accommodation.

Preliminary applications should be directed to Dr. V. Kalous, Department of Physical Chemistry, Charles University, Prague 2, Albertov 2030, from whom further information is available.

\section{Announcements}

Sir Richard vaN Der Riet Woolley, Astronomer Royal, has been elected president of the Royal Astronomical Society in succession to Prof. W. H. McCrea. Prof. McCrea has been president since 1961.

Mr. J. M. Olivant has been appointed to a new post of head of the Meat Section of the British Food Manu- facturing Industries Research Association. Mr. Olivant graduated at the Royal (Dick) School of Veterinary Studies of the University of Edinburgh, and from 1952 until 1959 was a lecturer in the University of Liverpool.

A symposium on "The Less Common Means of Separation", arranged by the Midlands Branch of the Institution of Chemical Engineers, will be held in Birmingham during April 25-26. Further information can be obtained from T. R. Bott, Department of Chemical Engineering, the University, Birmingham 15.

A symposium on "Catalysis in Practice", arranged with the co-operation of the Yorkshire Branch of the Institution of Chemical Engineers, will be held in Harrogate during June 20-21. Further information can be obtained from the General Secretary, Institution of Chemical Engineers, 16 Belgrave Square, London, S.W.1.

THE Centenary Meeting of the British Pharmaceutical Conference will be held in London during September 2-6. The programme will include: science and professional sessions; a symposium dealing with the subject of fine particles in pharmaceutical practice; a conversazione at the School of Pharmacy, University of London; excursions. The Conference Lecture will be given by Dr. J. M. Barnes, head of the Toxicology Research Unit of the Medical Research Council, who will discuss animal toxicity tests and their interpretation. Further information can be obtained from Dr. K. R. Capper, the British Pharmaceutical Conference, 17 Bloomsbury Square, London, W.C.l.

The Watford and District National Productivity Year Committee is organizing a symposium and exhibition on the "Effective Use of Information Services" which will be held at the Watford College of 'Technology on April 23. The programme of the symposium includes two lectures, namgly, "Technical and Seientific Information Services", by B. C. Viekery, deputy director, National Lending Library for Science and Technology (Department of Scientific and Industrial Research), and "Effective Use of Information Services", by R. Snel, head of technical information, Shell International Petroleum Co., London. Further information can be obtained from Mr. A. Short, Watford College of Technology, Hempstead Road, Watford, Herts.

THe fifteenth Hatfield Memorial Lecture will be delivered in Sheffield on May 8 by Prof. A. G. Quarrell, who has chosen as his subject "Metallography, a hundred years after Sorby". On the following day, May 9, there will be an all-day conference entitled "Sorby Centenary: Metallography 1963", sponsored by the Company of Cutlers in Hallamshire, the Iron and Steel Institute, the Institute of Metals, the Institution of Metallurgists, the Sheffield Motallurgical and Engineering Association and the University of Sheffield. In connexion with the conference, there will be an exhibition in the Drawing Room of the Cutlers' Hall, covering modern instruments used in metallography, photographs obtained by modern techniques, illustrating present-day research, and relies of H. C. Sorby. Further information can be obtained from the Iron and Steel Institute, 4 Grosvenor Gardens, London, S.W.1.

THE heading of the recent article "Investigation of the Radio Source $3 C 273$ by the Method of Lunar Occultations" (Nature, 197, 1037; 1963) unfortunately gave the impression that one of the authors, Dr. C. Hazard, is a member of the Radiophysics Division of C.S.I.R.O. as are the other two authors. Dr. Hazard is in fact a member of the Chatterton Astronomy Department, School of Physics, University of Sydnoy, and worked as a guest investigator on the Radiophysics Division's 210 -ft. telescope during the investigation in question, as stated in the last sentence of the article. 